\title{
Diagnostic role of C-Reactive Protein in Acute Appendicitis
}

\section{Ashis pun, ${ }^{1}$ Amit Dhungana, ${ }^{2}$ Ramjee Bastola' \\ 'Department of General Surgery, ${ }^{2}$ Department of Anaesthesiology, Bharatpur Hospital, Bharatpur-10, Chitwan, Nepal.}

\begin{abstract}
Introduction

Acute appendicitis is the common surgical disease however, accurate diagnosis and exclusion of acute appendicitis always remains challenge to the surgeons. Although diagnoses rely mostly on clinical examination but $\mathrm{C}$ - reactive protein (CRP) can be of valuable armamentarium. Hence, this study was conducted to find the diagnostic role of C-reactive protein in Acute Appendicitis
\end{abstract}

\section{Methods}

A retrospective cross sectional study was conducted among 100 respondents in the Department of Surgery, Bharatpur Hospital from September 2019 to August 2020. Ethical approval was taken from the Institutional Review Committee (IRC) Bharatpur Hospital. Statistical analysis was done by using SPSS version 16 using descriptive statistics.

\section{Results}

Total of 100 patients was included in study with mean age 31 years old.Out of which $60 \%$ were male and 40\% were female. CRP value was raised (>6) in 87 (87\%) cases and normal in 13(13\%) cases. Among those with raised CRP, three patients had normal appendix histopathologically and 57 had uncomplicated appendicitis and 27 had complicated appendicitis histopathologically with sensitivity, specificity, positive predictive value and diagnostic accuracy rate of 95.45\%, 75 $\%, 96.55 \%$ and $93 \%$ respectively. When white blood count (WBC) and CRP level were combined with HPE findings, its sensitivity, specificity and diagnostic accuracy rate were $100 \%, 80 \%$ and $93.83 \%$ respectively.

\section{Conclusions}

CRP improves the diagnostic accuracy of Acute appendicitis. The adjunct use of CRP and leucocyte count can effectively reduce the negative appendectomy rate.

Keywords: acute appendicitis; C-reactive protein; leucocyte; white blood cell.

Correspondance: Dr. Ashis Pun, Department of Surgery, Bharatpur Hospital, Bharatpur-10, Chitwan, Nepal. Email: ashis_pun@hotmail.com, phone: +977-9851094189. 


\section{INTRODUCTION}

Acute appendicitis is the most frequent cause of abdominal pain requiring surgery. An estimated $16 \%$ of people in western world require appendectomy at some stage during their life. ${ }^{1,2}$ Over the years, many studies have been done to improve the diagnostic accuracy in appendicitis but its accurate preoperative diagnosis still remains elusive. ${ }^{2,3,4}$ The diagnosis of acute appendicitis relies largely on clinical assessment, although both ultrasound and computed tomography (CT) can be helpful.

At any site of injury or inflammation macrophages and monocytes release soluble cytokines including IL-1, IL-6 and TNF-alpha. Some of these cytokines enter the circulation and exert pressure on bone marrow to increase production and release of leucocytes and on liver to increase production of CRP to combat infection. ${ }^{5}$

C-reactive protein is produced form liver to combat against the infection. CRP level help monitor inflammation/infection. Normal value is $<8 \mathrm{mg} / \mathrm{l}$. Like ESR, it is raised in many inflammatory conditions, but changes more rapidly; increases in hours and falling within 2-3 days of recovery. Therefore it can be used to follow the response to therapy or disease activity. CRP value in mild inflammation 10-15 $\mathrm{mg} / \mathrm{l}$; active bacterial infection $50-200 \mathrm{mg} / \mathrm{dl}$; severe infection or trauma $>200 \mathrm{mg} / 1 .^{6}$

The purpose of this study is to correlate the preoperative diagnostic accuracy and the predictive value of CRP in patients with acute appendicitis which can help the surgeon to come to an accurate diagnosis.

\section{METHODS}

A hospital based retrospective cross sectional study was conducted in the Department of Surgery, Bharatpur Hospital, Chitwan Nepal from June 2019 to May 2020. Ethical approval was taken from the institutional review committee
(IRC) Bharatpur Hospital (Ref No.17/076/77) and written consent was taken from all the study respondents. Sample size was calculated using pre-determined value of sensitivity using the formula $n=Z^{2} P q / d^{2}$. Pre-determined value of sensitivity or specificity was taken as 95.6 from the study conducted by Shafiet ${ }^{7}$ with $5 \%$ margin error. The minimum sample size of this study was found to be 64 . By adding extra $10 \%$ non response error, study was conducted among 100 respondents. Respondents were selected by using non probability sampling technique. Patients of aged $\geq 14$ years who presented with right lower quadrant pain and clinically diagnosed of acute appendicitis were included in study. Patients with diagnosis of recurrent appendicitis, appendicular lump and alternative diagnosis on intraoperative finding were not subjected to study. Similarly patients who were already on antibiotics before the blood sample was sent for laboratory analysis and patient with other systemic illness that effects WBC and CRP level like musculoskeletal disorders, pancreatitis etc were not enrolled in the study.

All the appendix were sent for histopathological reports. On the basis of operative findings and histopathological reports patients were categorized in Group A: normal (uninflamed appendix),Group B: uncomplicated (inflamed appendix)andGroupC:complicated (perforated/ gangrenous) CRP value is considered normal if $\leq$ $6 \mathrm{mg} / \mathrm{dl}$ and cut off value for increased leucocyte count is $11000 / \mathrm{mm}^{8}$ Self designed questionnaire was used to collect the data from the patients. Collected data were check for completeness and entered in Microsoft excel then analyzed using SPSS version 16. Data were analyzed by using descriptive. In the descriptive statistics frequency, percent mean and SD were used. By using cross tabulation sensitivity, specificity, positive and negative predictive values were calculated among the various parameters. 


\section{RESULTS}

A total of 100 respondents were included in the study in which $63 \%$ were aged below 30 years age and $37 \%$ were more than 30 years of age. The mean \pm SD of age of respondents was $31 \pm 15.31$ years. Also, $60 \%$ patients were male and $40 \%$ patients were female by gender. Histopathologically normal appendix was found in $12 \%$ cases, uncomplicated appendicitis in $61 \%$ cases and complicated appendicitis in $27 \%$ cases. White blood cell count (WBC) was increased $\left(>11,000\right.$ cells $\left./ \mathrm{mm}^{3}\right)$ in $86 \%$ of cases and normal in 14\%cases. CRP level was normal among $13 \%$ respondents and abnormal among $87 \%$ cases (Table 1).

Table 1. Baseline characteristics of the respondents.

\begin{tabular}{|c|c|c|}
\hline & & $n=100$ \\
\hline Variables & Frequency & Percent \\
\hline \multicolumn{3}{|l|}{ Age } \\
\hline$<30$ & 63 & 63.0 \\
\hline$\geq 30$ & 37 & 37.0 \\
\hline Mean(SD) & \multicolumn{2}{|c|}{$31 \pm 15.31$ years } \\
\hline \multicolumn{3}{|l|}{ Gender } \\
\hline Male & 60 & 60.0 \\
\hline Female & 40 & 40.0 \\
\hline \multicolumn{3}{|l|}{10} \\
\hline Gangrenous & 17 & 17.0 \\
\hline Inflamed & 70 & 70.0 \\
\hline Normal & 7 & 7.0 \\
\hline Perforated & 6 & 6.0 \\
\hline \multicolumn{3}{|l|}{ HPE } \\
\hline Normal & 12 & 12.0 \\
\hline Uncomplicated & 61 & 61.0 \\
\hline Complicated & 27 & 27.0 \\
\hline \multicolumn{3}{|l|}{ TLC } \\
\hline Normal & 14 & 14 \\
\hline Increased & 86 & 86 \\
\hline \multicolumn{3}{|l|}{ CRP } \\
\hline Normal & 13 & 13 \\
\hline Increased & 87 & 87 \\
\hline
\end{tabular}

Among those with increased WBC count, 27 patients $(100 \%)$ had complicated appendicitis with raised WBCs and 53 patients (86.89\%) of patientshadhistologically provenuncomplicated appendicitis with raised WBCs as in (Figure 1).

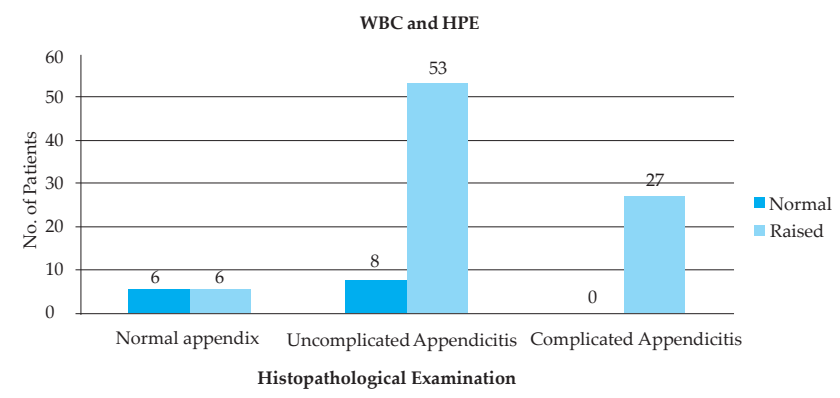

Figure 1. WBC and HPE of respondents.

CRP value was raised (>6) in 87 (87\%) cases and normal in $13(13 \%)$ cases. Among those with raised CRP, three patients had normal appendix histopathologically and 57 patients (93.44\%) had uncomplicated appendicitis and 27 patients (100\%) had complicated appendicitis histopathologically with raised CRP (Figure 2). CRP and HPE

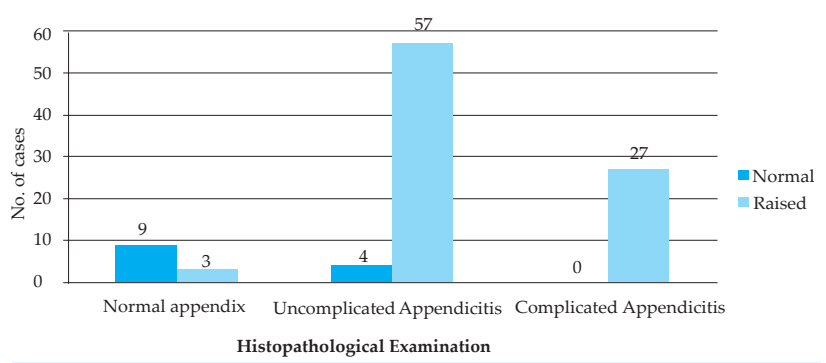

Figure 2. CRP and HPE of respondents.

The sensitivity, specificity, positive predictive value, negative predictive value, diagnostic accuracy rate of CRP was $95.45 \%, 75 \%, 96.55 \%$ , 69.23\% and 93\% respectively with $\mathrm{P}$ value: $<0.001$ (Table 3).

Table 3. The sensitivity, speci icity, positive predictive value, negative predictive value, of CRP.

\begin{tabular}{|l|l|l|l|}
\hline $\begin{array}{c}\text { Serum C- } \\
\text { reactive } \\
\text { Protein }\end{array}$ & $\begin{array}{c}\text { Histologically } \\
\text { Appendicitis }\end{array}$ & $\begin{array}{c}\text { Histologically } \\
\text { Normal Appendix }\end{array}$ & Total \\
\hline Raised & 84 (TP) & 3 (FP) & 87 \\
\hline Normal & 4 (FN) & $9(\mathrm{TN})$ & 13 \\
\hline Total & 88 & 12 & 100 \\
\hline
\end{tabular}

TP: true positive; TN: true negative; FP: false positive; FN: false negative 
WBC and CRP were both raised in 79 cases, out of which 76 patients had positive HPE findings and three patients had negative HPE findings. In four cases both WBC and CRP were normal and HPE findings also showed normal appendix. There was no histologically proven appendicitis when both WBC and CRP were normal as in (Table 4).

\begin{tabular}{|c|c|c|c|c|}
\hline \multicolumn{5}{|c|}{$\begin{array}{l}\text { Table 4. Relationship between } \\
\text { WBC with HPE findings. }\end{array}$} \\
\hline \multirow{2}{*}{ WBC / CRP } & \multicolumn{3}{|c|}{ HPE } & \multirow{2}{*}{ Total } \\
\hline & Appendicitis & Normal & Appendix & \\
\hline Normal & 0 & & 4 & 4 \\
\hline Raised & 76 & & 1 & 77 \\
\hline Total & 76 & & 5 & 81 \\
\hline
\end{tabular}

When both CRP and WBC was combined and compared with HPE, sensitivity, specificity and diagnostic accuracy rate were100\%, $80 \%$ and $93.83 \%$ respectively

\section{DISCUSSION}

The diagnosis of appendicitis can be very challenging due to its wide variety in clinical presentation. To overcome this diagnostic dilemma modern diagnostic tools like ultrasonography, Computed tomography (CT) and various scoring system like Alvarado, modified Alvarado, Tzanaki, Lintula, Paediatric Appendicitis Score (PAS), Raja IsteriPengiranAnakSaleha Appendicitis (RIPASA) and Appendicitis Inflammatory Response (AIR) are introduced. Implementation of these diagnostic tools and scoring systems hasshown some improvement but these modern tools are not easily available at all hospitals. Although various studies have been conducted,here we attempt to evaluate CRP which can be easily performed in most of the hospitals and compare it with leucocyte count and HPE report to see its diagnostic essence.

In our study, the sensitivity and specificity of CRP level is $95.45 \%$ and $75 \%$ respectively.
The positive predictive value of CRP is 96.55 $\%$ and negative predictive value is $69.23 \%$. The diagnostic accuracy rate is $93 \%$ and $\mathrm{P}$ value is $<0.001$ which is statistically significant. This finding is comparable to the study done by Gurleyik E. et alwhere the sensitivity, specificity and accuracy of serum CRP measurements were calculated as $93.5 \%, 80 \%$ and $91 \%$ respectively. ${ }^{9}$ Whereas our results were superior to that by Shafi S.M and collegues where sensitivity, specificity and positive predictive value were $98.9 \%, 38.88 \%$ and $89.21 \%{ }^{8}$ In a double blind study by Asfar S. et al, ${ }^{10}$ the specificity and sensitivity of CRP level was $86.6 \%$ and $93.6 \%$ concluding that normal CRP level in suspected appendicitis is most likely to be associated with normal appendix. In contrary, study done by Agrawal C.S et $\mathrm{al}^{11}$ and Jangjoo A et $\mathrm{al}^{12} \mathrm{CRP}$ level was not found to be a good indicator of appendicitis with sensitivity and specificity of $78.8 \%$ and $66.7 \%$ by Agrawal CS and sensitivity and specificity of $59 \%$ and $68 \%$ by Janjoo A. However in a meta-analysis done by Hallan $S$ et al it showed that CRP performed is better and statistically significant. ${ }^{13}$ Similarly john S.K et al also found CRP better with sensitivity of $98 \%$ and specificity of $87 \%$ with $P$ value $<0.0001$ comparable to our study. ${ }^{14}$

At present study, when both leucocyte count and CRP were combined and compared with HPE positive finding, sensitivity increased to $100 \%$ and specificity increased to $80 \%$ and diagnostic accuracy of $93.82 \%$. This showed that normal leucocyte and CRP level patients subjected for operative management should be thought twice and planned for other diagnostic modalities like CT scan. Our result was comparable with study done by Mohammed A.A et $\mathrm{al}^{15}$ with sensitivity and specificity of $86 \%$ and $90.7 \%$ and John S.K et $\mathrm{al}^{14}$ with sensitivity of $100 \%$ and diagnostic accuracy of $92 \%$. In a cross sectional study done by Siddique $\mathrm{K}$ et $\mathrm{al}^{16} \mathrm{combined}$ sensitivity of 
WBC and CRP increased to $95 \%$ and $100 \%$ for diagnosis of uncomplicated appendicitis and complicated appendicitis respectively.

In this study, total complicated appendicitis cases were found in 27 patients and WBC was raised in all case (100\%). Likewise CRP was also raised in all cases of complicated appendicitis $(100 \%)$. In all cases (61 cases) of uncomplicated appendicitis WBC count was raised by $86.89 \%$ and CRP was raised by $93.4 \%$. This showed that WBC and CRP also help to estimate the severity of the disease. This present study is comparable to the study done by Sulberg D et $\mathrm{al}^{17}$ where it showed strong CRP correlation with respect to the grade of inflammation and

\section{REFERENCES}

1. Bailey $H$, Love $M$. The vermiform appendix. In: Williams NS, Bulstrode CJK, O'Connell PR, editors. Bailey and Love's Short Practice of Surgery. 25th ed. London: Edward Arnold (Publishers) Ltd; 2008. p. 1204-18.

2. Sengupta A, Bax G, Paterson-brown S. White cell count and C-reactive protein measurement in patients with possible appendicitis. Ann R Coll Surg Engl [Internet]. 2009;91(2):113-5. Available from: pubmed.ncbi.nlm.nih. gov/19102827/

3. Sellars H, Boorman P.Acute appendicitis. Surgery [Internet]. 2017;1-7. Available from: $\quad$ http://dx.doi.org/10.1016/j. mpsur.2017.06.002

4. Standring S, editor. Gastrointestinal Tract- Large Intestine Vermiform appendix. In: Gray's Anatomy- The Anatomical Basis of Clinical practice. 39th ed. Philadelphia: Elsevier Churchill Livingstone; 2008. p. 1366-7. perforation. Similar finding was also observed in study by Vaugh-Shaw PG et alwhere CRP, WBC and neutrophil combined were able to differentiate between normal, uncomplicated and complicated appendicitis. ${ }^{18}$

\section{CONCLUSIONS}

Although the diagnosis of acute appendicitis mostly relies on clinical evaluation, we suggest CRPlevel measurement is useful in assessment of acute appendicitis. Besides, we also found that combined analysis of CRP and WBC parameters can spare a group of patients from unnecessary surgical procedure.

\section{Conflict of interest: none}

5. Ralston S, Penman I, Strachan M, Hobson R. Musculoskeletal Disorders. In: Doherty M, Lanyon P, Ralston SH, editors. Davidson's Principles and Practice of Medicine. 20th ed. London: Elsevier Churchill Livingstone; 2007. p. 1065-144.

6. Longmore $\mathrm{M}$, Wilkinson I, Baldwin A, Wallin E. Clinical Chemistry. 7th ed. Oxford Handbook of Clinical Medicine. London: Oxford University Press; 2007. 652-85 p.

7. Hajian-tilaki K. Sample size estimation in diagnostic test studies of biomedical informatics. J Biomed Inform [Internet]. 48:193-204. Available from: http://dx.doi. org/10.1016/j.jbi.2014.02.013

8. Shafi SM, Afsheen M, Reshi FA. Total Leucocyte Count, C-reactive Protein and Neutrophil Count: Diagnostic Aid in Acute Appendicitis. Saudi J Gastroenterol. 2009;15(2):117-20.

9. Gurleyik E, Gurleyik G, Unalmiser S. Accuracy of Serum C-Reactive Protein Measurements in Diagnosis of Acute 
Appendicitis Compared with Surgeon's Clinical Impression. Dis Colon Rectum. 1995;38(12):1270-4.

10. Asfar S, Safar H, Khoursheed M, Dashti $\mathrm{H}$, Al-Bader A. Would measurement of C-reactive protein reduce the rate of negative exploration for acute appendicitis? J R Coll Surg Edinb. 2000;45(1):21-4.

11. Agrawal CS, Adhikari S, Kumar M. Role of serum C- reactive protein and leukocyte count in the diagnosis of acute appendicitis in Nepalese population. Nepal Med Coll J [Internet]. 2008;10(1):11-5. Available from: https:// pubmed.ncbi.nlm.nih.gov/18700623/

12. Jangjoo A, Varasteh AR, Bahar MM, Meibodi NT, Aliakbarian M, Hoseininejad $M$, et al. Is C-reactive protein helpful for early diagnosis of acute appendicitis? Acta Chir Belg. 111(4):219-22.

13. Hallan S, Asberg A. The accuracy of C-reactive protein in diagnosing acute appendicitis - a meta-analysis. Scand J Clin Lab Invest. 1997;57(5):373-80.

14. John SK, Joseph J, Shetty SR. Avoiding negative appendectomies in rural surgical practice: Is C-reactive protein estimation useful as a diagnostic tool ? Natl Med J India. 2011;24(3):144-7.

15. Mohammed AA, Daghman NA, Aboud SM, Oshibi HO. The diagnostic value of C-reactive protein, white blood cell count and neutrophil percentage in childhood appendicitis. Saudi Med J. 25(9):1212-5.

16. Siddique $K$, Baruah $P$, Bhandari S, Mirza $S$, Harinath G. Diagnostic accuracy of white cell count and C-reactive protein for assessing the severity of paediatric appendicitis. J R Soc Med Sh Rep. 2011;2(7):1-6.

17. Sülberg D, Chromik AM, Kersting S, Meurer K, Tannapfel A, Uhl W, et al. Appendicitis in the elderly. CRP value as decision support for diagnostic laparoscopy. Chirurg [Internet]. 80(7):608-14. Available from: https:// pubmed.ncbi.nlm.nih.gov/19562239/

18. Vaughan-Shaw PG, Rees JR, Bell E, Hamdan M, Platt T. Normal inflammatory markers in appendicitis: evidence from two independent cohort studies. JRSM Short Rep [Internet]. 2011;2(5):43. Available from: https://pubmed.ncbi.nlm. nih.gov/21637404/

Citation: Pun A, Dhungana A, Bastola R. Diagnostic role of C-Reactive Protein in Acute Appendicitis. JCMS Nepal. 2020; $16(4): 246-51$. 